IZA DP No. 5734

A Note on Inequality Aversion Across Countries, Using Two New Measures

Diane J. Macunovich

May 2011 


\title{
A Note on Inequality Aversion Across Countries, Using Two New Measures
}

\author{
Diane J. Macunovich \\ University of Redlands \\ and IZA
}

\section{Discussion Paper No. 5734 \\ May 2011}

IZA

P.O. Box 7240

53072 Bonn

Germany

Phone: +49-228-3894-0
Fax: +49-228-3894-180
E-mail: iza@iza.org

Any opinions expressed here are those of the author(s) and not those of IZA. Research published in this series may include views on policy, but the institute itself takes no institutional policy positions.

The Institute for the Study of Labor (IZA) in Bonn is a local and virtual international research center and a place of communication between science, politics and business. IZA is an independent nonprofit organization supported by Deutsche Post Foundation. The center is associated with the University of Bonn and offers a stimulating research environment through its international network, workshops and conferences, data service, project support, research visits and doctoral program. IZA engages in (i) original and internationally competitive research in all fields of labor economics, (ii) development of policy concepts, and (iii) dissemination of research results and concepts to the interested public.

IZA Discussion Papers often represent preliminary work and are circulated to encourage discussion. Citation of such a paper should account for its provisional character. A revised version may be available directly from the author. 
IZA Discussion Paper No. 5734

May 2011

\section{ABSTRACT}

\section{A Note on Inequality Aversion Across Countries, Using Two New Measures}

Studies using the Gini Index as a measure of income inequality have consistently found a positive and significant effect of the Gini on both happiness and life satisfaction. Two new measures used here - the ratio of persons in the lowest income decile relative to the number in the highest, and the ratio of the number in the lowest social class relative to the number in the highest, in a given country - as developed from the World Values Survey data, are shown here to have a negative and significant effect on both happiness and life satisfaction. This effect holds overall across countries, and for individuals within most income and class categories.

JEL Classification: I3

Keywords: inequality, happiness, life satisfaction

Corresponding author:

Diane J. Macunovich

Department of Economics

University of Redlands

Redlands, CA 92346

USA

E-mail: diane_macunovich@redlands.edu 
Although there is an extensive literature on the effects of income on subjective well-being (SWB), there is considerably less on the impact of inequality in income across countries, or within countries. And yet there seems ample evidence that a whole host of social ills - crime, drug use, ill health and shortened life expectancy, among others - result from higher levels of inequality (Wilkinson and Pickett, 2009). One would expect, therefore, that there would be a commensurate negative impact on SWB. In fact, however, some studies that have done work with the Gini coefficient and other objective measures of income and wealth inequality have tended to find a positive impact on either reported happiness, or life satisfaction, or both, when looking across countries.

Much of the inequality literature is dominated by studies which examine the effects of relative income measures, rather than strict inequality measures. That is, researchers have developed variables that relate an individual's personal income to the average income in a country, region, state, city, or cohort, and test the response of reported SWB to the difference between, or ratio of, these two measures. This gives an estimate of an individual's response to personal deprivation or benefit, but not a response to the overall, less personal, income inequality in society as a whole, which is the focus of this study. Because many of these studies are referred to as tests of the responsiveness of SWB to inequality, they are reviewed here for comprehensiveness.

\section{Review of Relative Income Studies}

Blanchflower and Oswald (2004) conducted analyses of the effect of relative income on happiness for the US, using data from the General Social Survey (GSS), 1972-1998. (Their analysis included some work with British data, as well, but no relative income variable was tested there.) Logged state income per capita had an insignificant negative effect in the regressions, and a relative income variable (the ratio of own to state income) produced a significant positive effect. Adding the average incomes in the first and fifth quintiles, in a regression with own income, produced a negative effect of the first quintile average and a positive effect of the fifth quintile average - both statistically significant. They interpreted these 
results as indicating that people compare themselves more to those with higher incomes, and derive pleasure from being closer to a higher income.

Dynan and Ravina (2007) again used the GSS - 1979-2004 - for the US, to estimate another relative income variable. In this case, it was the ratio of the average real earnings in an individual's educationoccupation-state-year cohort, to the average state-year real earnings. Their results were somewhat easier to interpret, than those of Blanchflower and Oswald. They found that happiness in groups with belowaverage earnings was negatively affected by this relative income variable, but with a small magnitude, while the happiness of above average individuals was positively affected, to a greater extent. In other tests using the income in the 90th percentile as a benchmark, they found that relative income concerns primarily affect people with above-average income who are not extremely rich.

Another relative income analysis was conducted for the US by Luttmer (2005), who looked at an individual's income relative to that in the neighboring area. He used the National Survey of Families and Households (1987-88 and 1992-94), and found the expected positive and significant effect of own income, with an equal but negative effect of the average income in an individual's surrounding area. He found that the effect was strongest for those who socialized most in the neighborhood, who presumably were more aware of general income levels. This corresponded with results of McBride (2001), who used 324 observations from the 1994 GSS to test the effect of parents' income and birth cohort average income on life satisfaction. He found a negative effect of these two variables, which was larger at higher incomes, whereas a positive effect of own income was strongest at low income levels.

Brockmann, Delhey, Welzel and Yuan (2009) conducted another relative income analysis, this time for China, using the World Values Survey (WVS) data for 1990 and 2000, a period when the national Gini coefficient rose from .28 to .43 . They tested a ratio of own income to the national mean, without a control for own income, and found a significant positive effect in 2000. Smyth and Qian (2008) also used 
Chinese data - a survey of 31 cities - and found a negative effect of relative income (the average income in each city), when it was entered separately from own income. In addition, they tested for the effect of an individual's perception of inequality, and found a significant negative effect among those with low incomes, but a positive effect for those with high incomes.

D'Ambrosio and Frick (2007) conducted a similar analysis using the German Socio-Economic Panel (GSOEP), 1990-2004. They calculated, for each individual, a "relative deprivation" measure, the gaps between own income and all of the incomes above his, as a proportion of mean income. In an equation with own income, they estimated a significant positive effect of own income, and, unlike Brockmann et al., a significant negative effect of relative deprivation, on satisfaction with own income.

Graham and Felton (2006) looked at the effects of both the Gini and two relative wealth measures on Latin American countries, using the Latiobarometro survey 1997-2004. They found no significant effect of the Gini coefficient, and no effect of average wealth at the national level, but a negative and significant effect of average wealth at the city level (assigning each individual the overall averages for rural areas, medium sized cities and metropolitan areas). Breaking it down by income quintile, they found that the effect was negative and significant for people in the bottom two quintiles, and positive and significant for people in the top two income quintiles.

Thus if one could hazard a generalization about these findings, it would be that relative income effects if they are measured using some type of overall average - seem to be negative for those at lower income levels, and positive for those above the mean.

\section{Review of Inequality Studies}

One of the earliest of these - a hybrid of relative income and inequality - was conducted by Tomes (1986), who used data from the Canadian Quality of Life Survey for 1977, to analyze the effects of the 
share of income going to the bottom $40 \%$ and top $10 \%$ of the income distribution in 200 Federal Electoral Districts, on self-reported happiness and life satisfaction. He found a significant effect only on life satisfaction, not on happiness, and it was an unexpected one: a negative effect of the share going to the bottom $40 \%$. He found no significant effect of the average level of income, however - his relative income measure.

O'Connell (2004) also used income quintiles, but in this case it was the ratio of the income going to the top quintile, to that going to the bottom quintile. He used country-level panel data for $15 \mathrm{EU}$ countries from the Eurobarometer 1995-1998, and found a significant negative impact on life satisfaction. This result was confirmed by the later findings of Ebert and Weksch (2009), again using the Eurobarometer data, but this time for 10 European countries for the period 1978-1997. In addition, instead of using a ratio variable, they tested the effects of a variety of objective inequality measures, including the Gini. They found a significant level of inequality aversion, but the degree depended on the measure used.

Schwarze and Harpfer (2007) had similar results for Germany, using the GSOEP data from 1985-1998 for life satisfaction. They estimated the effects of inequality pre- and post- government redistribution, and found inequality aversion at all income levels pre-redistribution, but negative effects only on the bottom income tercile after redistribution. However, they found that the percent reduction in inequality from redistribution had a negative impact on the middle tercile - although this effect was significant only at the $10 \%$ level. And, using the Swiss Household Panel, Winkelman and Winkelman (2002) found a significant negative effect of local Gini coefficients, as well as the concentration of luxury cars, on life satisfaction.

Similarly, Oshio and Kobayashi (2010) found a negative effect of regional Gini coefficients on both life satisfaction and reported health in Japan, using the Japanese GSS and the Comprehensive Survey of Living Conditions of People on Health and Welfare for 2001, 2004 and 2007. 
However, using the World Values Survey data (WVS) for 41 countries in the third wave (1995-1997), Haller and Hadler (2006) found a significant positive effect of the Gini coefficient on both happiness and life satisfaction (although only at the $10 \%$ level). They attributed this to the fact that the Latin American countries, which have high levels of inequality, report themselves as high in SWB, while the former Eastern Bloc countries, which have egalitarian societies, report themselves as low in SWB. However, they also hypothesized that this was a result of a marked positive correlation they said they observed between countries' GDP, and their Gini coefficients. More will be said about this later.

This conflicting result is supported to some extent by Alesina, DiTelia and MacCulloch (2004), using data from the GSS for the US from 1981-1996 together with Gini coefficients of after tax, after transfer income by state. While they found that over all, people in the US displayed a significant negative response to inequality, when they broke this down into left and right ideologies, they found that there was a significant negative effect only for those on the left, and even this became insignificant after controlling for unemployment. Breaking the sample into "poor" and "rich" produced negative and significant coefficients only for the rich, and that effect remained even after controlling for unemployment. They attributed the lack of impact for the poor, to the prevailing sense of upward mobility in the US. However, for Europe, with the Eurobarometer Survey from 1975-1992, and a question on life satisfaction, they found a significant negative effect of inequality after controlling for unemployment over all, for those on the left, and for the poor, as measured by the Gini coefficient. However, in all of these regressions, whether for Europe or the US, the estimated coefficients even when insignificant were always negative.

And finally, in a micro-level analysis, at the university level in the US, Pfeffer and Langton (1993) found a strong inverse relationship between satisfaction and the degree of wage dispersion. 
Thus we have a consistently negative and significant impact of inequality in European countries and Japan, but a less consistent one in the US - and a positive effect in Canada and across 41 countries in the mid 1990s.

It is unclear why the Gini coefficient should be positively related to happiness and life satisfaction, since in the first decade of the 21st century the Gini is negatively correlated with GDP $(r=-0.3588)$ and GDP has been found consistently to be positively related to both happiness and life satisfaction. The aim of this study is first to test the cross-country effect of the Gini coefficient using the 56 countries in the 2005 wave of the WVS, and then to compare that result to one using two alternate measures of inequality constructed from two of the self-reported variables in the World Values Survey data.

\section{Data and Methodology}

The data used here are taken from the 2005 wave of the World Values Survey (http://worldvaluessurvey.org) which, for the variables used here, contains data on 56 countries (listed in Appendix A). There were between 1,000 and 3,000 interviews of adults 18 and over conducted in each country between the years 2004-2007, with an average survey size of 1,456. Unlike in previous waves, in most countries in this Wave, this was a nationally representative sample, and in the US, for example, there was a $70.2 \%$ response rate.

The four questions used in this analysis were the following:

Happiness: "Taking all things together, would you say you are:

Very Happy

Rather happy

Not very happy

Not at all happy"

(Although in the original survey data this variable was scaled as 1="Very happy" to 4="Not at all Happy", for the purposes of this analysis it has been re-scaled from 1="Not at all happy" to 4="Very happy".) 
Life Satisfaction: "All things considered, how satisfied are you with your life these days? Using this scale where one means you are completely dissatisfied and ten means you are completely satisfied, where would you put your satisfaction with your life as a whole?"

Social Class: "People sometimes describe themselves as being in the working class, the middle class, or the upper or lower class. Would you describe yourself as belonging to the

Upper class

Upper middle class

Lower middle class

Working class

Lower class"

Income Scale: "Here is a scale of incomes on which 1 indicates the "lowest income decile", and 10 indicates the "highest income decile" in your country. We would like to know in what group your household is. Please, specify the appropriate number, counting all wages, salaries, pensions and other incomes that come in."

For this last question, the respondent was shown a card indicating income ranges corresponding to each of the ten numbers. (In some countries, the survey was self-administered by computer, so there was a display window used.) The question is a rather imprecise one, since different scales were used in different countries, and there seems to be little pattern in terms of which ones, if any, actually made use of income deciles. In fact, given the tabulations shown later, it is impossible that they were actual income deciles, since very different proportions of the samples fell into different ranges. However, this is what makes the variable potentially useful, since it permits the development of a type of measure using the ratio of the numbers at the top and bottom of the income scale. Less reliance is placed on this variable, though, than on the Social Class variable.

The method used here in the development of subjective measures of income inequality, was to calculate a ratio of the (weighted) number in the bottom category ("Lower class", in the case of social class, and Group 1, in the case of the income scale) to the (weighted) number in the top class ("Upper class" in the case of social class, and Group 10, in the case of the income scale). The first of these, especially, using the Social Class variable, can be thought of as a more subjective measure of inequality, and one to which people might be more sensitive, than a Gini coefficient. The higher the ratio, the greater the degree of 
subjective inequality. Thus, unlike the case with the Gini coefficient, the hypothesis here is that one would find a negative relationship between these measures, and both Happiness and Life Satisfaction (when Happiness is measured as 1="Not at all happy" to 4="Very Happy") - that is, that across countries, as has been found in Europe, people are inequality averse.

The response rates on the four questions used in the analysis are presented in Table 1 . Table 2 presents the distribution of the population across the range of values for Life satisfaction and Happiness, while Table 3 presents statistics for the two inequality measures. All responses were weighted in the analysis, using the weights provided in the WVS. Regressions were estimated using ordered probit, and standard errors were clustered at the country level.

\section{$\underline{\text { IV.Results }}$}

The results of the analyses are presented in Tables $4-7$. Tables 4 and 5 present overall results for each of the two dependent variables, Happiness and Life Satisfaction, respectively - that is, for regressions over the entire population, not broken down by subgroup. In Table 4 we can see the unexplained estimated positive effect of the Gini coefficient on Happiness (.018, significant at the .05 level), as in the work by Haller and Hadler (2006). The coefficient on the Income Ratio is negative (-.004) and significant at the .01 level, however, indicating a level of inequality aversion across countries that contradicts the findings using the Gini coefficient. The coefficient on the Class Ratio is significant only at the .15 level, however, but it too is negative (-.001).

The effects of the control variables in Table 4 are similar to those estimated in other studies: positive and significant coefficients on income and for those who are married, and negative and significant for men and for those who are widowed, unemployed, or retired. There is an estimated U-shaped pattern in age. 
Table 5 presents equivalent results for Life Satisfaction. Here too, the Gini coefficient displays a positive coefficient (.024, significant at the .05 level). But once again the coefficients on the Income Ratio and the Class Ratio are both negative (with the coefficient on the class ratio significant at the .01 level, but that on the Income Ratio significant only at the .20 level).

Thus the coefficient on the Class Ratio is negative and significant for Life Satisfaction, whereas the coefficient on the Income Ratio is negative and significant for Happiness.

The effects of the various control variables are very similar in Table 5, to those in Table 4, with the exceptions being that here there are additional negative and significant coefficients for the self-employed and those in Other unspecified activities. The effect of age is again U-shaped.

Tables 6 and 7 present results for individual subgroups in the population - that is, by income level and by social class. Only the coefficients on the three inequality variables are shown, although all regressions contained the same control variables as in Tables 4 and 5.

Table 6, for Happiness, displays positive coefficients on the Gini coefficient for all income and class groups, that are statistically significant for deciles 1, 2, 3 and 5, and for the Upper Middle and Upper classes. The Income Ratio, however, displays negative and significant coefficients for deciles 1, 2, 3, 4, and 6 - and, more consistently than the Gini, displays negative and significant coefficients for all but the Upper class group. Thus, the lower income and class groups are all inequality averse. Five of the coefficients for the Class Ratio are statistically significant (and negative), but they display no particular pattern. This is consistent with the lack of statistical significance overall for the Class Ratio in Table 4.

Table 7, for Life Satisfaction, displays positive coefficients on the Gini coefficient for all income and class groups, that are statistically significant for those in deciles 1 through 4 , and for the Lower, Upper 
Middle and Upper classes. The Class Ratio, however, displays negative and significant coefficients for all income and class groups except for those in the two upper deciles and those in the Lower class. And even for these three groups, the estimated effect is still negative. Only three of the estimated coefficients for the Income Ratio are statistically significant, however - for deciles 1 and 2, those in the Lower class but all estimated coefficients are, again, negative. This is consistent with the lack of statistical significance overall for the Income Ratio's effect on Life satisfaction in Table 5.

\section{$\underline{\text { V. Summary }}$}

The results presented here suggest that, across countries, people are adversely sensitive to crowding at the lower end of the income and class scales. The ratio of the number of individuals in the lowest income group, relative to the number in the highest group, is estimated to have a negative and significant effect on measured Happiness, when Happiness is measured on a scale from 1="not at all happy" to 4="very happy". And the ratio of the number in the lowest social class relative to the number in the highest is estimated to have a significantly negative effect on Life Satisfaction, ranked from 1="completely dissatisfied" to $10=$ "completely satisfied". This is in contrast to the estimated effect of the Gini coefficient, which is found to have an estimated positive and significant effect on both measures of subjective well-being. 


\section{Bibliography}

Alesina, Alberto, Rafael Di Telia and Robert MacCulloch (2004). Inequality and happiness: are Europeans and Americans different? Journal of Public Economics. 88: 2009-2042.

Barrett, J.Douglas, Kristen Van rensselaer and Bruce Gordon (2007). Possible Effects of National Homogeneity on Happiness. Journal of International Business Research, 6(1):49-60.

Blanchflower, D and A Oswald (2004). Well-Being Over Time in Britain and the USA. Journal of Public Economics, 88:1359-1386.

Brockmann, Hilke, Jan Delhey, Christian Welzel, Hao Yuan (2009) The China Puzzle: Falling Happiness in a Rising Economy. Journal of Happiness Studies. 10(4): 387

D'Ambrosio, Conchita and Joachim Frick (2007). Income Satiisfaction and Relative Deprivation: An Empirical Link. Social Indicators Research, 81:497-519.

Dynan, Karen E. and Enrichetta Ravina (2007). Increasing Income Inequality, External habits, and SelfReported Happiness. American Economic Review, 97(2):226-231.

Ebert, Udo and Heinz Weksch (2009). How Do Europeans Evaluate Income Distribution? An Assessment Based on Happiness Surveys. The Review of Income and Wealth, 55(3):803-819.

Graham, Carol and Andrew Felton (2006). Inequality and Happiness: Insights from Latin America. Journal of Economic Inequality, 4:107-122.

Haller, Max and Markus Hadler (2006). How Social relations and Structures Can Produce Happiness and Unhappiness: An International Comparative Analysis. Social Indicators Research, 75:169-216.

Hopkins, Ed (2008). Inequality, Happiness and relative Concerns: What actually is Their relationship? Journal of Economic Inequality 6:351-372.

Kalmijn WM, LR Arends (2011) Erratum to: Measures of Inequality: Application to Happiness in Nations. Social Indicators Research. 100(2): 367

Kalmijn WM, LR Arends (2011) Measures of Inequality: Application to Happiness in Nations. Social Indicators Research. 99(1): 147

Karlsson, Martin and Carl Hampus Lyttkens (2010) Health. Happiness. Inequality. Expert Review of Pharmacoeconomics \& Outcomes Research. 10(5): 497

Luttmer, Erzo (2005). Neighbors as Negatives: Relative Earnings and Well-Being. Quarterly Journal of Economics, 120(3):963-1002.

McBride, Michael. (2001). Relative-Income Effects on Subjective Well-Being in the Cross Section. Journal of Economic Behavior and Organization, 45(3): 251-78.

O'Connell, Michael (2004). Fairly satisfied: Economic Equality, Wealth and Satisfaction. Journal of Economic Psychology. 25(3): 297 
Oshio, Takashi and Miki Kobayashi (2010) Income Inequality, Perceived Happiness, and Self-rated Health: Evidence from nationwide surveys in Japan. Social Science \& Medicine. 70(9): 1358

Pfeffer, Jeffrey and Nancy Langton (1993). The Effect of Wage Dispersion on Satisfaction, Productivity and Working Collaboratively: Evidence from college and University Faculty. Administrative Science Quarterly, 38(3):382-407.

Schwarze. Johannes and Marco Härpfer (2007). Are People Inequality Averse, and do They Prefer Redistribution by the State? Journal of Socio-Economics. 36: 233249.

Senik, Claudia (2005). Income Distribution and Well-Being: What Can We Learn from Subjective Data? Journal of Economic Surveys, 19(1):43-63.

Smyth, Russell and Xiaolei Qian (2008). Inequality and Happiness in Urban China; Economics Bulletin, 4(24): $1-10$

Tomes, Nigel (1986). Income Distribution, Happiness and Satisfaction: A Direct Test of the Interdependent Preferences Model. Journal of Economic Psychology. 7(4): 425-446.

Wilkinson, Richard and Kate Pickett (2009). The Spirit Level: Why Greater Equality Makes Societies Stronger. Bloomsbury Press: New York.

Weisbach, DA (2008). What Does Happiness Research Tell Us about Taxation?" Journal of Legal Studies $37: 293$.

Wilkinson, Richard and Kate Pritchett (2009). The Spirit Level: Why Greater Equality Makes Societies Stronger.

Winkelmann, Liliana and Rainer Winkelmann (2010). Does Inequality Hurt the Middle Class? Kyklos, 63(2):301-316.

Wolff, Edward and Ajit Zacharias (2007). The Impact of Wealth Inequality on Economic Well-Being. Challenge, July-August: 65-87.

World Values Survey 2005 Official Data File v.20090901, 2009. World Values Survey Association (www.worldvaluessurvey.org). Aggregate File Producer: ASEP/JDS, Madrid. 


\begin{tabular}{|c|c|c|c|c|c|c|c|}
\hline \multicolumn{8}{|c|}{ Table 1: Response Rate to Four Questions Used in the Analysis } \\
\hline Question & & Numl & r of coun & es by res & sse rate & & Total \\
\hline & $95-99 \%$ & $90-94 \%$ & $80-89 \%$ & $70-79 \%$ & $60-69 \%$ & $0 \%$ & \\
\hline Happiness & 55 & - & 1 & - & - & - & 56 \\
\hline Life satisfaction & 54 & 2 & - & - & - & - & 56 \\
\hline Social class & 32 & 12 & 5 & - & - & 7 & 56 \\
\hline Income scale & 18 & 17 & 9 & 4 & 1 & 7 & 56 \\
\hline
\end{tabular}

\begin{tabular}{|l|c|c|c|c|c|c|}
\hline \multicolumn{7}{|c|}{ Table 2: Distributions of Reported Life Satisfaction and Happiness } \\
(with Happiness scored 1="not at all happy" to 4="very happy")
\end{tabular}

\begin{tabular}{|l|l|l|}
\hline \multicolumn{3}{|l|}{ Table 3: Descriptive Statistics for the Two Inequality Measures } \\
\hline & Income ratio & Class ratio \\
\hline mean & 20.08 & 30.10 \\
\hline std.deviation & 36.42 & 73.29 \\
\hline minimum & 0.20 (Russia) & 0.29 (Switzerland) \\
\hline maximum & 183 (China) & 432 (Rwanda) \\
\hline 10th percentile & 0.71 & 2.55 \\
\hline 25th & 1.99 & 3.77 \\
\hline 50th & 7.78 & 10.07 \\
\hline 75th & 21.38 & 27.74 \\
\hline 90th & 42.20 & 46.08 \\
\hline Missing values & 7 & 7 \\
\hline Total & 56 & 56 \\
\hline
\end{tabular}


Table 4: Ordered Probit Regressions of Happiness on Three Measures of Inequality

\begin{tabular}{|c|c|c|c|c|c|c|}
\hline \multicolumn{7}{|c|}{ Happiness (scaled 1= not at all happy to 4=very happy) } \\
\hline & coefficient & $\mathbf{z}$ & coefficient & $\mathbf{z}$ & coefficient & $\mathbf{z}$ \\
\hline Income ratio & $-0.004 * * *$ & -2.46 & & & & \\
\hline Class ratio & & & -0.001 & -1.62 & & \\
\hline Gini index & & & & & $0.018 * *$ & 2.20 \\
\hline Income level & $0.123 * * *$ & 5.20 & $0.167 * * *$ & 8.19 & $0.144 * * *$ & 6.30 \\
\hline Male & $-0.155 * * *$ & -2.56 & $-0.151 * * *$ & -2.48 & $-0.085 * *$ & -2.03 \\
\hline Age & $-0.048 * *$ & -6.89 & $-0.045 * * *$ & -6.17 & $-0.050 * * *$ & -7.59 \\
\hline Age squared & $0.001 * * *$ & 7.57 & $0.0005 * * *$ & 6.52 & $0.001 * * *$ & 7.63 \\
\hline $\begin{array}{l}\text { Completed high } \\
\text { school }\end{array}$ & 0.068 & 0.94 & 0.062 & 0.82 & 0.056 & 0.88 \\
\hline Completed college & 0.040 & 0.46 & 0.026 & 0.29 & $0.155^{*}$ & 1.87 \\
\hline Married & $0.236^{* * *}$ & 3.92 & $0.231 * * *$ & 3.78 & $0.278 * * *$ & 6.23 \\
\hline Separated & -0.128 & -1.25 & -0.151 & -1.21 & -0.175 & -1.58 \\
\hline Divorced & $-0.177^{*}$ & -1.73 & -0.041 & -0.45 & -0.096 & -0.92 \\
\hline Widowed & $-0.451 * * *$ & -5.28 & $-0.425^{* * *}$ & -5.13 & $-0.470 * * *$ & -5.70 \\
\hline Unemployed & $-0.465 * * *$ & -6.30 & $-0.407 * * *$ & -5.25 & $-0.467 * * *$ & -5.41 \\
\hline Self employed & 0.026 & 0.28 & 0.051 & 0.59 & -0.033 & -0.35 \\
\hline Retired & $-0.337 * * *$ & -2.57 & $-0.264 * *$ & -1.92 & $-0.293 * *$ & -2.39 \\
\hline Housewife & -0.199 & -1.38 & -0.209 & -1.52 & -0.074 & -0.81 \\
\hline Student & -0.026 & -0.30 & 0.079 & 0.97 & -0.012 & -0.15 \\
\hline Other & $-0.239 * * *$ & -2.50 & -0.084 & -0.69 & -0.112 & -0.95 \\
\hline ----------- & |----------- & -------- & ------------ & - -------- & ------------ & -------- \\
\hline /cut1 & -4.106 & & -3.708 & & -3.397 & \\
\hline /cut2 & -2.116 & & -1.714 & & -1.235 & \\
\hline /cut3 & 0.445 & & 0.932 & & 1.356 & \\
\hline Observations & 67981 & & 64544 & & 68116 & \\
\hline Pseudo-R Sq & 0.0256 & & 0.0283 & & 0.0277 & \\
\hline
\end{tabular}


Table 5: Ordered Probit Regressions of Life Satisfaction on Three Measures of Inequality

\begin{tabular}{|c|c|c|c|c|c|c|}
\hline \multicolumn{7}{|c|}{ Life Satisfaction (scaled $1=$ dissatisfied to $10=$ satisfied) } \\
\hline & coefficient & $\mathbf{z}$ & coefficient & $\mathbf{z}$ & coefficient & $\mathbf{z}$ \\
\hline Income Ratio & -0.005 & -1.53 & & & & \\
\hline Class Ratio & & & $-0.003^{* * *}$ & -4.66 & & \\
\hline Gini Index & & & & & $0.024 * *$ & 2.16 \\
\hline Income level & $0.158^{* * *}$ & 4.11 & $0.211 * * *$ & 8.79 & $0.170 * * *$ & 5.56 \\
\hline Male & $-0.134 * * *$ & -2.30 & $-0.140 * * *$ & -2.49 & $-0.080 * *$ & -1.87 \\
\hline Age & $-0.034 * * *$ & -5.69 & $-0.034 * * *$ & -5.49 & $-0.034 * * *$ & -4.96 \\
\hline Age squared & $0.0004 * * *$ & 6.89 & $0.0004 * * *$ & 6.33 & $0.0004 * * *$ & 5.75 \\
\hline $\begin{array}{l}\text { Completed high } \\
\text { school }\end{array}$ & 0.081 & 1.17 & 0.057 & 0.84 & 0.058 & 0.91 \\
\hline Completed college & 0.103 & 1.16 & 0.108 & 1.35 & $0.236 * * *$ & 2.81 \\
\hline Married & $0.121 * *$ & 1.99 & $0.130 * *$ & 2.10 & $0.148 * * *$ & 2.66 \\
\hline Separated & 0.051 & 0.61 & 0.041 & 0.44 & 0.027 & 0.30 \\
\hline Divorced & -0.060 & -0.57 & 0.055 & 0.70 & 0.014 & 0.15 \\
\hline Widowed & $-0.311^{* * *}$ & -4.50 & $-0.289 * * *$ & -4.04 & $-0.350 * * *$ & -4.66 \\
\hline Unemployed & $-0.534 * * *$ & -5.43 & $-0.481 * * *$ & -5.01 & $-0.608 * * *$ & -5.07 \\
\hline Self employed & $-0.266 * * *$ & -2.67 & -0.099 & -1.11 & $-0.292 * * *$ & -2.51 \\
\hline Retired & -0.186 & -1.35 & -0.117 & -0.88 & -0.175 & -1.39 \\
\hline Housewife & -0.211 & -1.16 & -0.228 & -1.34 & -0.069 & -0.57 \\
\hline Student & $-0.209 * *$ & -1.87 & -0.111 & -1.10 & $-0.234 * *$ & -2.20 \\
\hline Other & $-0.328 * * *$ & -2.67 & $-0.191 * *$ & -1.77 & $-0.245^{* *}$ & -2.00 \\
\hline ------------- & ------------ & ----------- & ------------- & ---------- & ------------- & -------- \\
\hline /cut1 & -3.475 & & -3.229 & & -2.484 & \\
\hline /cut2 & -2.905 & & -2.639 & & -1.880 & \\
\hline /cut3 & -2.260 & & -1.962 & & -1.186 & \\
\hline /cut4 & -1.755 & & -1.439 & & -0.668 & \\
\hline /cut5 & -0.925 & & -0.584 & & 0.158 & \\
\hline /cut6 & -0.394 & & -0.013 & & 0.697 & \\
\hline /cut7 & 0.292 & & 0.713 & & 1.396 & \\
\hline /cut8 & 1.272 & & 1.719 & & 2.372 & \\
\hline /cut9 & 2.021 & & 2.504 & & 3.133 & \\
\hline Number of Obs & 68019 & & 64532 & & 68098 & \\
\hline Pseudo-R Square & 0.0184 & & 0.026 & & 0.0186 & \\
\hline
\end{tabular}


Table 6: Happiness Regressed on the Gini Index and Two Subjective Ratios, by Income and Class

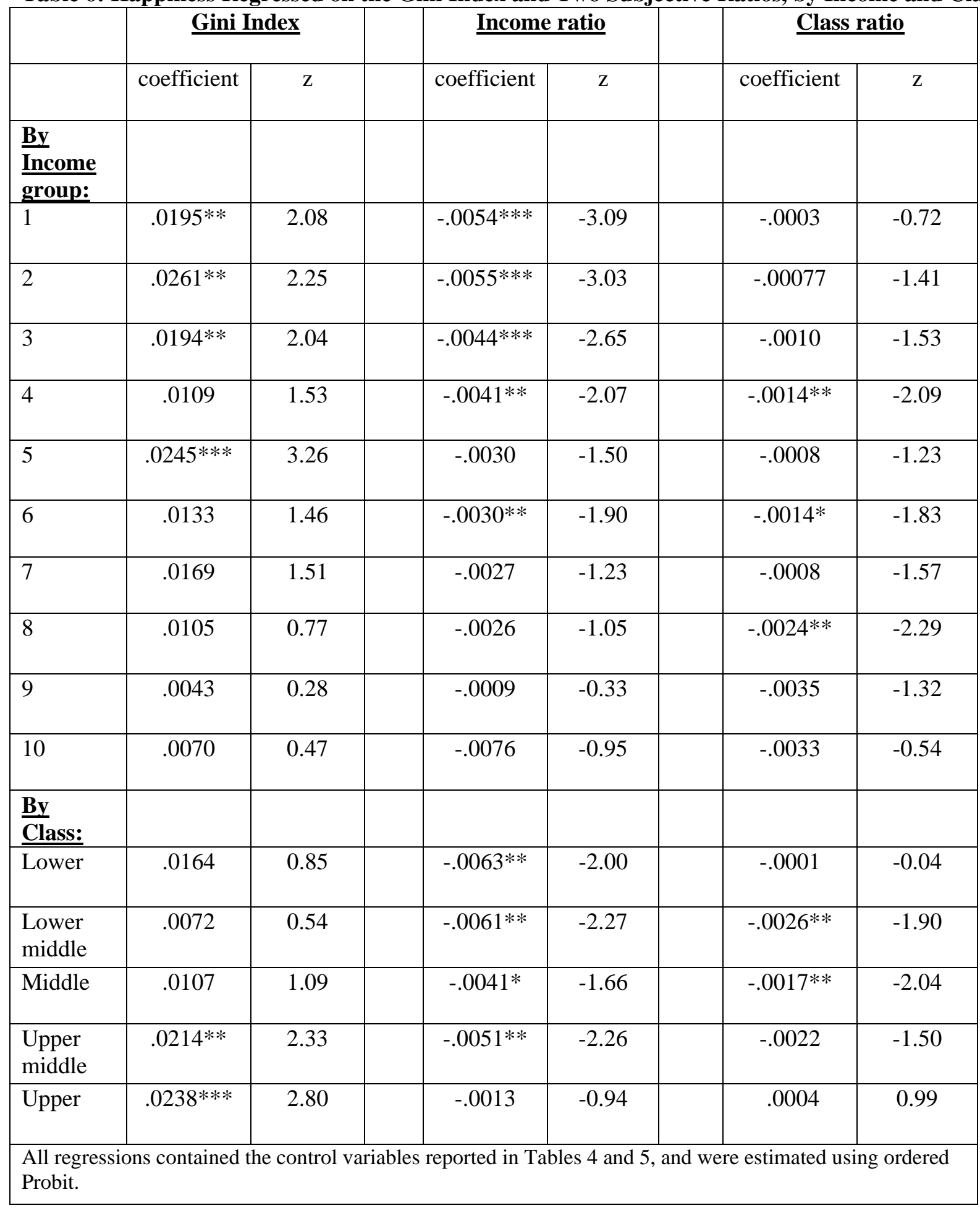


Table 7: Life Satisfaction Regressed on the Gini Index and Two Subjective Ratios

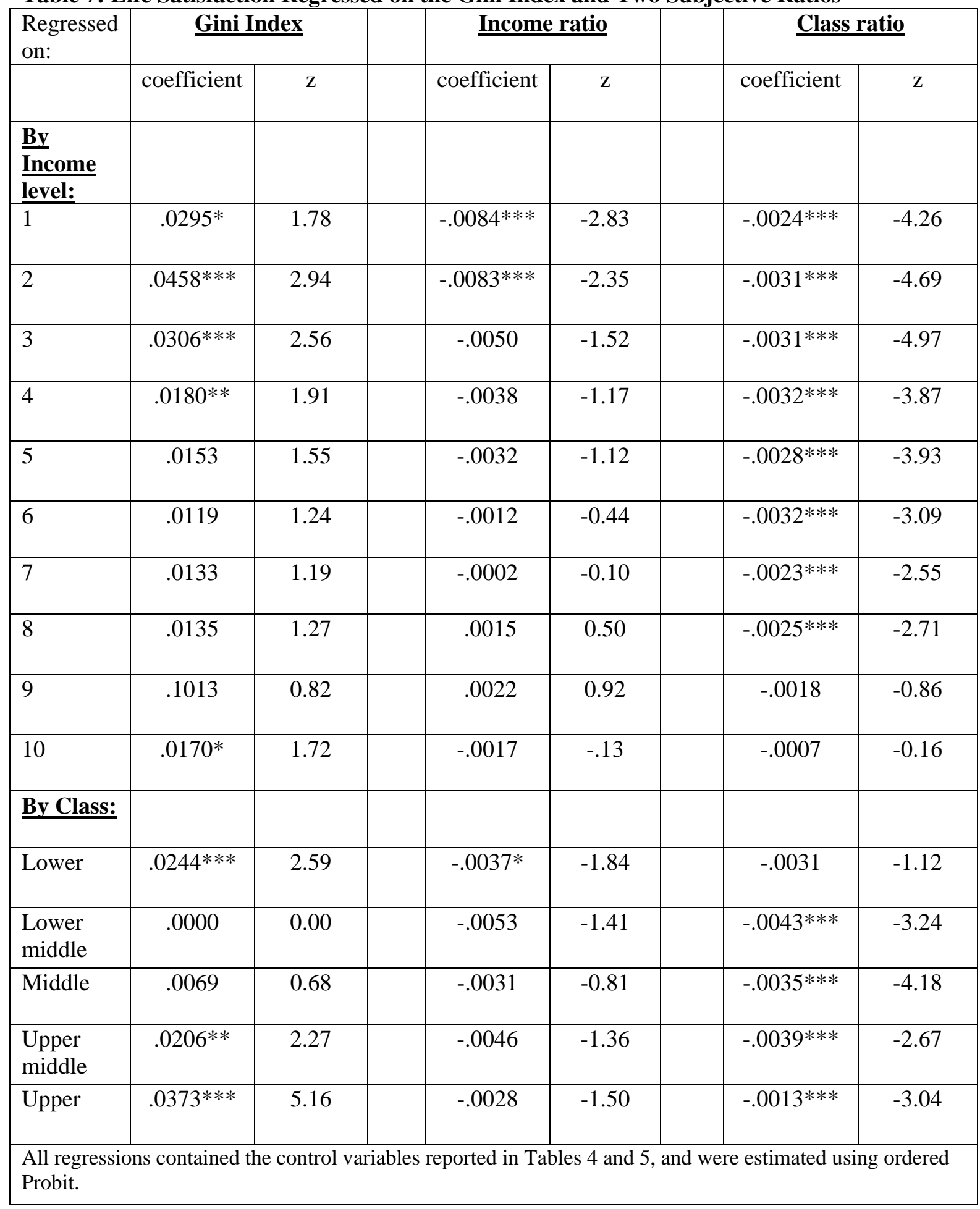

